\title{
Efek Suction Melalui Catheter Mouth terhadap Saturasi Oksigen Pasien Cedera Kepala
}

\author{
Marlisa $^{1}$, Ponpon S Idjradinata ${ }^{2}$, Cecep Eli Kosasih ${ }^{3}$ \\ ${ }^{1}$ Poltekkes Kemenkes Medan, ${ }^{2}$ RSUP Dr. Hasan Sadikin, ${ }^{3}$ Fakultas Keperawatan Universitas \\ Padjadjaran \\ E-mail:marlisaicha@yahoo.co.id
}

\begin{abstract}
Abstrak
Tindakan suction endotracheal pada pasien cedera kepala berat dapat menyebabkan terjadinya oxygen desaturation arteri yang berakibat pada peningkatan intracranial pressure, pembengkakan otak dan hipoksemia sistemik bahkan dapat menyebabkan kematian. Penelitian ini bertujuan untuk mengevaluasi pengaruh suplai oksigen melalui catheter mouth saat suction terhadap saturasi oksigen pada pasien cedera kepala yang terpasang ventilator yang dirawat di ruang perawatan intensif. Penelitian ini menggunakan desain penelitian desain kuasi eksperimen pendekatan pre dan post test dengan kelompok kontrol dan perlakuan. Jumlah sampel pada penelitian ini adalah 40 responden yang dibagi menjadi kelompok perlakuan sebanyak 20 responden yang dipasang catheter mouth dan kelompok kontrol sebanyak 20 responden tanpa menggunakan catheter mouth. Teknik sampel menggunakan accidental sampling. Penurunan saturasi oksigen nilai $t$ hitung $(-16,538)<t$ tabel $(-2,024)$ dan nilai $p$-value $(0.000)<0.05$. Saturasi oksigen saat suction pada kelompok kontrol dengan kelompok perlakuan adalah memang berbeda secara nyata. Hasil penelitian ini dapat dijadikan evidence based bagi perawat di ruang intensif untuk meningkatkan pelayanan perawatan dalam melakukan tindakan suction untuk mengurangi resiko terjadinya penurunan saturasi oksigen pada pasien cedera kepala berat yang terpasang ventilator.
\end{abstract}

Kata kunci : catheter mouth, suction, saturasi oksigen.

\section{The Effect of Oxygen Supply Via Oral Catheterization in the Suction Process to the Oxygen Saturation Level in the Patient with Head Injury}

\begin{abstract}
The intervention of endotracheal suction to patients with the severe head injury may have effected to oxygen desaturation in arteries. The oxygen desaturation process could be impacted to increase the intracranial pressure, brain's swelling, hypoxemia systemic, and deaths. This study aimed to evaluate the influence of the oxygen supply via oral catheterization in the suction process to the oxygen saturation level in the patient with the severe head injury who using ventilator. This research has been conducted in the intensive care unit. This study was applied the quasi experiment design using pre and post-test. Samples were chosen using accidental sampling. There were two groups of samples, the first group was the intervention group with 20 respondents using oral catheterization, and the second group was the control group with 20 respondents. The result showed that the oxygen saturation was reduced with $t$ value $(-16.538)<\mathrm{t}$ table $(-2.024)$, and $\mathrm{p}$ value $(0.000)<0.05$. The oxygen saturation was significantly different between two groups. This study could be an evidence that nurses should enhance their services to reduce the risk of decreasing the oxygen saturation in the severe head injury patient who using ventilator.
\end{abstract}

Key words: Catheter Mouth, oxygen saturation, suction. 
Marlisa: Suplai Oksigen melalui Catheter Mouth pada Saat Suction

\section{Pendahuluan}

Kecelakaan lalu lintas merupakan masalah kesehatan masyarakat di seluruh dunia, khususnya di negara berkembang. Menurut World Health Organization (WHO) pada tahun 2002 kecelakaan lalu lintas merupakan penyebab kematian urutan kesebelas di seluruh dunia, menelan korban jiwa sekitar 1,2 juta manusia setiap tahun. (Almgren, Carl, Heinonen, \& Hogman, 2004).

Menurut WHO tahun 2004, Case Fatality Rate (CFR) cedera akibat kecelakaan lalu lintas tertinggi dijumpai di beberapa negara berkisar antara $21 \%-41,7 \%$. Di Amerika Serikat, kejadian cedera kepala setiap tahunnya diperkirakan mencapai 500.000 kasus. Dari jumlah tersebut, 10\% meninggal sebelum tiba di rumah sakit. Insiden cedera kepala terutama terjadi pada kelompok usia produktif antara 15-44 tahun. (Ragnarsson \& Kristjan, 2006).

Kejadian cedera kepala khususnya di Jawa Barat dilaporkan yang masuk Rumah Sakit Umum Pusat Dr. Hasan Sadikin Bandung pada tahun 2009 tercatat 1.378 kasus, sedangkan pada tahun 2010 berjumlah 1.095 kasus cedera kepala yang dirawat dan memerlukan penanganan medis baik dirawat di ruang perawatan intensif maupun yang dirawat di ruangan (Rekam Medis RSHS).

Pasien dengan cedera kepala berisiko terjadinya kerusakan otak akibat perdarahan atau pembengkakan otak sebagai respon terhadap cedera dan menyebabkan peningkatan Intracranial Pressure (ICP) yang dapat berakibat buruk terhadap pusat pernapasan selanjutnya dapat menimbulkan penurunan denyut jantung. Karena kondisi tersebut, pasien yang mengalami cedera kepala memerlukan pemantauan yang cermat, kolaborasi yang baik antara perawat dan dokter, serta pemberian terapi secara tepat dan cepat .

Penanganan pasien cedera kepala berat yang mengalami peningkatan ICP dan gangguan oksigenasi adalah dengan melakukan resusitasi otak selama satu sampai tiga kali dalam 24 jam. Agar tindakan resusitasi otak dapat tercapai dengan baik, pasien mutlak harus dirawat di ruang perawatan intensif (Ragnarsson \& Kristjan 2006).

Pasien cedera kepala yang masuk ke ruang perawatan intensif rata-rata perbulan pada tahun 2010 adalah $17-20$ orang. Saat pasien masuk, pasien dilakukan pemasangan endo tracheal tube (ETT) dan pemasangan ventilator pada mode continuous mandatory ventilation (CMV) (Rekam Medis RSHS).

Selama pemasangan ventilator dengan mode CMV, pasien diberikan sedasi, analgesik yang adekuat, dan muscle relaxan. Dalam keadaan demikian, pasien tidak mampu mengeluarkan sekreta secara mandiri. Untuk menjaga jalan napas tetap bersih dan oksigenasi tetap adekuat, dilakukan penghisapan yang dikenal dengan tindakan suction (Hudak \& Gallo, 2010).

Penurunan saturasi oksigen pada pasien yang dirawat di ruang intensif saat tindakan suction pada pasien dengan ventilator dengan mode CMV masih tinggi (Almgren, dkk., 2004). Upaya yang dilakukan untuk mengurangi kejadian tersebut adalah dengan membuat standar prosedur operasional untuk tindakan suction. Setiap melakukan tindakan tersebut, semua perawat harus sesuai dengan standar operasional yang ada dan menggunakan kateter suction sistem tertutup. Upaya alternatif lain sangat diperlukan untuk mengatasi masalah tersebut yaitu dengan memberikan oksigen langsung pada saat suction yaitu dengan menggunakan catheter mouth yang dipasang di antara endo tracheal tube (ETT) dan ventilator saat tindakan suction.

Berdasarkan paparan di atas yang menjadi rumusan masalah dalam penelitian ini adalah apakah terdapat perbedaan saturasi oksigen saat dilakukan suction pada pasien cedera kepala yang terpasang ventilator menggunakan catheter mouth dengan yang tidak menggunakan catheter mouth. Penelitian ini bertujuan untuk mengevaluasi pengaruh suplai oksigen melalui catheter mouth saat suction terhadap saturasi oksigen pada pasien cedera kepala yang terpasang ventilator di ruang perawatan intensif Rumah Sakit Umum Pusat Dr. Hasan Sadikin Bandung.

\section{Metode Penelitian}

Penelitian ini adalah penelitian kuantitatif, dengan desain penelitian menggunakan 
Marlisa: Suplai Oksigen melalui Catheter Mouth pada Saat Suction

metode kuasi eksperimen. Desain penelitian ini menggunakan pretest-posttest dengan kelompok kontrol. Rancangan penelitian ini mengelompokan anggota-anggota kelompok kontrol dan kelompok perlakuan berdasarkan acak (Dahlan, 2009).

Populasi dalam penelitian ini adalah subjek yang memenuhi kriteria inklusi yang telah ditetapkan yaitu semua pasien cedera kepala berat yang terpasang ventilator dengan mode controlled mandatory ventilation (CMV) atau mode kontrol yang masuk ke ruang perawatan general intensive care unit (GICU) dan neurosurgical critical care unit (NCCU) RSUP Dr. Hasan Sadikin Bandung dari tanggal 14 April 2011 sampai dengan tanggal 14 Juni 2011. Teknik sampling yang digunakan pada penelitian ini adalah accidental sampling, merupakan suatu teknik pengambilan sampel dengan mengambil kasus atau responden yang kebetulan ada atau tersedia. Teknik sampling ini digunakan karena waktu dan kasus yang akan dicari terbatas. Setiap pasien cedera kepala yang masuk dilakukan pengacakkan dengan cara diberikan penomoran ganjil untuk kelompok kontrol dan penomoran genap untuk kelompok perlakuan (Wheeless, 2010).

Pada penelitian ini sampel didapat dari seluruh pasien cedera kepala berat glasgow coma scales (GCS) $(3-8)$ dengan CMV yang dirawat di ruang perawatan GICU dan NCCU Rumah Sakit Dr. Hasan Sadikin Bandung dari tanggal 14 April 2011 sampai dengan 14 Juni 2011. Jumlah sampel yang akan diteliti sebanyak 40 orang, yang terbagi menjadi dua kelompok yaitu kelompok kontrol (tanpa catheter mouth) dan kelompok perlakuan (dengan catheter mouth).

Karekteristik sampel yang dimasukkan dalam kriteria inklusi pada penelitian ini meliputi: (1) pasien cedera kepala berat GCS (3-8), (2) umur 15-50 tahun, laki-laki dan perempuan, (3) pasien dengan CMV. Kriteria eksklusif adalah dengan menghilangkan/ mengeluarkan subjek yang tidak memenuhi kriteria inklusi atau tidak layak diteliti untuk menjadi sampel, yaitu (1) pasien cedera kepala ringan dan sedang tanpa ventilator, (2) pasien dengan komplikasi paru-paru dan jantung, (3) pasien dalam proses penyapihan. Alat untuk memonitor saturasi oksigen adalah pulse oxymetri, dimana alat ini merupakan alat bantu sederhana dengan metode non invasif untuk memantau kadar saturasi oksigen darah arteri kapiler. Nilai normalnya adalah 95-100\%. Suplai oksigen adalah penyediaan atau pemberian oksigen yang diinginkan untuk pemenuhan kebutuhan oksigen sesuai yang ditargetkan (Guyton \& Hall, 2008). Catheter mouth with extendible tubing adalah suatu alat yang berbentuk Y yang dipasang antara ETT dan ventilator dengan tubing yang diperpanjang. Dengan menggunakan catheter mouth, maka suplai oksigen dari ventilator akan tetap adekuat. Berbeda dengan tanpa catheter mouth maka biasanya perawat melakukan dengan metode konvensional di mana antar selang ETT dilepas sehingga suplai oksigen dari ventilator terputus dan tidak adekuat. Ethical clearance yang dilakukan adalah penelitian dilakukan setelah peneliti mendapatkan surat ijin dan rekomendasi dari Komite Etik Penelitian Kesehatan Fakultas Kedokteran Universitas Padjadjaran Bandung dan rumah sakit tempat penelitian. Peneliti melakukan sendiri pengumpulan data penelitian berupa data karekteristik sampel, observasi tindakan suction serta data saturasi oksigen. Setelah mendapat ijin dari pihak rumah sakit, peneliti mengadakan pendekatan dengan calon responden yang diwakili oleh keluarga responden yang memenuhi kriteria inklusi, karena kondisi responden yang tidak sadar untuk memberikan penjelasan tentang tujuan, manfaat dan prosedur penelitian. Apabila keluarga bersedia maka diminta untuk menandatangani lembar persetujuan (informed consent).

Responden dikelompokkan menjadi dua kelompok yaitu kelompok I adalah kelompok perlakuan yang menggunakan catheter mouth sedangkan kelompok II adalah kelompok kontrol tanpa menggunakan catheter mouth. Peneliti menentukan pasien pada kelompok kontrol yaitu pasien dengan penomoran ganjil sedangkan pasien pada kelompok perlakuan adalah pasien dengan nomor genap, kemudian pasien diberikan nomor urut responden sesuai dengan kelompoknya pada lembar penelitian. Peneliti melakukan observasi pelaksanaan tindakan suction sesuai protokol penelitian dan prosedur tetap yang ada di ruangan. 
Marlisa: Suplai Oksigen melalui Catheter Mouth pada Saat Suction

\section{Hasil Penelitian}

Pada penelitian ini dapat dilihat bahwa responden pada kelompok kontrol dan perlakuan terbanyak berkisar antara umur 15-20 tahun, sebanyak 10 orang (50\%) pada kelompok perlakuan sedangkan pada kelompok kontrol sebanyak sembilan orang $(45 \%)$. Jenis kelamin responden pada kelompok kontrol dan perlakuan terbanyak yaitu laki-laki sebanyak 37 orang $(92,5 \%)$. Dimana pada kelompok kontrol ditemukan jumlah laki-laki sebanyak 17 orang $(85 \%)$ dan perempuan sebanyak tiga orang $(15 \%)$. Sedangkan pada kelompok perlakuan hanya ditemukan pasien laki-laki saja yaitu sebanyak 40 orang $(100 \%)$.

Pada tabel 1 ditemukan bahwa dari jumlah 20 responden kelompok kontrol, saturasi oksigen sebelum tindakan suction yang paling dominan adalah $100 \%$ sebanyak 17 orang $(85 \%)$ sedangkan saturasi oksigen yang paling dominan saat suction adalah 94\% sebanyak enam orang $(30 \%)$.

Pada tabel 2 ditemukan bahwa dari jumlah 20 responden kelompok perlakuan, saturasi oksigen sebelum tindakan suction yang paling dominan adalah $100 \%$ sebanyak 18 orang $(90 \%)$ sedangkan saturasi oksigen yang paling dominan saat tindakan suction adalah 99\% sebanyak 10 orang (50\%).

Pada kelompok kontrol terjadi penurunan skor saturasi oksigen dengan rerata penurunan skor 6,60 dari rerata skor 99,85 sebelum dilakukan tindakan suction menjadi 93,25 setelah dilakukan tindakan suction tanpa menggunakan catheter mouth. Sedangkan pada kelompok perlakuan terjadi penurunan skor saturasi oksigen dengan rerata penurunan skor 0.75 dari rerata skor 99,85 sebelum dilakukan tindakan suction menjadi 99,10 setelah dilakukan tindakan suction dengan menggunakan catheter mouth. Ternyata secara rata-rata kelompok perlakuan lebih tinggi dibandingkan kelompok kontrol, hal tersebut menunjukkan bahwa saturasi oksigen saat suction tanpa suplai oksigen lebih tinggi penurunannya dibandingkan dengan yang diberikan suplai oksigen.

Uji normalitas saturasi oksigen sebelum dan saat suction pada masing-masing kelompok kontrol dan kelompok perlakuan dapat dilihat bahwa pada masing-masing kelompok nilai $p$ value $>0.05$ maka Ho diterima. Hasil ini membuktikan bahwa data saturasi oksigen saat suction dilihat dari masing-masing kelompok kontrol dan kelompok perlakuan berasal dari populasi yang berdistribusi normal.

Perbandingan Saturasi Oksigen rata-rata sebelum dan Saat Suction antara Kelompok Kontrol dengan Kelompok Perlakuan.

Dengan derajat kepercayaan sebesar 95\%, pada perbandingan kelompok kontrol dengan kelompok perlakuan didapat nilai t hitung $(-16,538)<$ t tabel $(-2,024)$ dan nilai $p$ value

Tabel 1 Data Saturasi Oksigen Sebelum dan Saat Tindakan Suction pada Kelompok Kontrol

\begin{tabular}{ccccc}
\hline \multirow{2}{*}{ Saturasi Oksigen } & \multicolumn{2}{c}{ Sebelum Suction } & \multicolumn{3}{c}{ Saat Suction } \\
\cline { 2 - 5 } & $\mathbf{n}$ & $\mathbf{\%}$ & $\mathbf{n}$ & $\mathbf{\%}$ \\
\hline 100 & 17 & 85 & 0 & 0 \\
99 & 3 & 15 & 0 & 0 \\
98 & 0 & 0 & 0 & 0 \\
97 & 0 & 0 & 0 & 0 \\
96 & 0 & 0 & 0 & 0 \\
95 & 0 & 0 & 4 & 20 \\
94 & 0 & 0 & 6 & 30 \\
93 & 0 & 0 & 4 & 20 \\
92 & 0 & 0 & 4 & 20 \\
91 & 0 & 0 & 1 & 5 \\
90 & 0 & 0 & 1 & 5 \\
\hline
\end{tabular}


Marlisa: Suplai Oksigen melalui Catheter Mouth pada Saat Suction

Tabel 2 Data Saturasi Oksigen Sebelum dan Saat Tindakan Suction pada Kelompok Perlakuan

\begin{tabular}{ccccc}
\hline \multirow{2}{*}{ Saturasi Oksigen } & \multicolumn{2}{c}{ Sebelum Suction } & \multicolumn{2}{c}{ Saat Suction } \\
\cline { 2 - 5 } & $\mathbf{n}$ & $\mathbf{\%}$ & $\mathbf{n}$ & $\mathbf{\%}$ \\
\hline 100 & 18 & 90 & 6 & 30 \\
99 & 1 & 5 & 10 & 50 \\
98 & 1 & 5 & 4 & 20 \\
\hline
\end{tabular}

$(0.000)<0.05$. Hal ini menunjukkan bahwa saturasi oksigen saat suction pada kelompok kontrol (tanpa suplai oksigen) dengan kelompok perlakuan (dengan suplai oksigen) memang berbeda secara nyata.

\section{Pembahasan}

1. Hasil perubahan penurunan skor nilai ratarata antara kelompok

Saturasi oksigen sebelum tindakan suction pada kelompok kontrol dan perlakuan yang paling dominan adalah 100\% sebanyak 35 orang. Hal tersebut didukung oleh pendapat RW Light, dkk., bahwa saturasi oksigen sebelum tindakan suction sebagian besar adalah 100\%. Kondisi tersebut disebabkan karena pasien diberikan hiperoksigenasi sebelumnya dengan melakukan hiperinflasi yaitu memberikan fraksi oksigen $100 \%$ pada ventilator selama dua menit. Pemberian oksigenasi ini bertujuan untuk mempercepat dan memperlama transportasi oksigen ke jaringan sehingga diharapkan saat tindakan suction pasien tidak mengalami penurunan saturasi oksigen yang drastis (Hudak \& Gallo, 2010).

Kelompok kontrol terjadi penurunan skor saturasi oksigen dengan rerata penurunan skor 6,60 dari rerata skor 99,85 sebelum dilakukan tindakan suction menjadi 93,25 setelah dilakukan tindakan suction tanpa menggunakan catheter mouth, sedangkan pada kelompok perlakuan terjadi penurunan skor saturasi oksigen dengan rerata penurunan skor 0.75 dari rerata skor 99,85 sebelum dilakukan tindakan suction menjadi 99,10 setelah dilakukan tindakan suction dengan menggunakan catheter mouth. Berdasarkan hasil di atas dapat disimpulkan bahwa pada kelompok kontrol terjadi penurunan skor saturasi oksigen lebih besar dibandingkan dengan kelompok perlakuan di mana terlihat penurunannya pada kelompok kontrol yaitu 6.60 sedangkan pada kelompok perlakuan adalah 0.75 (Morrow, Futter, \& Argen, 2006).

Menurut penulis hal ini terjadi karena pada kelompok kontrol yang tidak menggunakan catheter mouth digunakan sistem suction terbuka (open suction) dimana selang yang menghubungkan selang endotracheal dengan selang ventilator dilepas sehingga pada saat penghisapan tersebut dilakukan tanpa suplai oksigen yang adekuat. Sedangkan pada kelompok perlakuan sudah terpasang catheter mouth sehingga pelaksanaan suction dilakukan tanpa perlu melepaskan selang endotracheal dengan selang ventilator sehingga oksigenasi dari ventilator ke pasien tetap adekuat selama pelaksanaan tindakan penghisapan (suction) tersebut, sehingga desaturasi oksigen dapat dikurangi (Reilly \& Bullock, 2007).

Hal ini karena pada saat suction endotracheal dapat terjadi tekanan negatif di trakea sehingga menimbulkan risiko kerusakan paru parsial yang dapat menyebabkan penurunan saturasi oksigen dan hilangnya volume paru-paru (Almgren, dkk., 2004). Komplikasi yang paling sering terjadi akibat tindakan suction adalah terjadinya hipoksemia. Pengaruh dari kejadian hipoksemia akan menyebabkan terjadinya keadaan hipoksia, di mana pasien yang sedang dalam kondisi kritis ditambah dengan kejadian hipoksia akan memperburuk kondisi pasien (Lindgren, 2007). Kondisi ini juga dapat disebabkan karena penggunaan catheter mouth pada kelompok perlakuan sehingga masih terjadi atau berlangsung suplai oksigen yang adekuat dari ventilator ke pasien pada saat dilakukan tindakan suction sedangkan pada kelompok kontrol yang tidak terpasang catheter mouth, pada saat dilakukan suction walaupun diberikan 
$\mathrm{FiO}_{2}$ sebesar $100 \%$ terjadi penurunan yang sangat signifikan karena suplai oksigen tidak dialirkan secara adekuat dengan dilakukannya pemutusan selang $\mathrm{Y}$ yang menghubungkan selang endotracheal dengan ventilator diputus yang menyebabkan suplai oksigen tidak adekuat (Sole, 2005).

Pada penelitian yang lain tentang suction sistem tertutup yang mengevaluasi apakah sebuah suction terbuka berpengaruh terhadap infeksi silang dan analisis perubahan dalam pertukaran gas dibandingkan dengan sistem tertutup pada pasien yang dipasang ventilator mekanik di ruang intensif (AARC Clinical Practice Guidelines, 2010), dimana evaluasi meliputi pencatatan jumlah suctioning per hari selama pelaksanaan manuver suction. Selanjutnya saturasi oksigen sebelum dan segera setelah suction tercatat. Pasien menghirup oksigen selama 2 menit sebelum suction dengan oksigen $100 \%$. Hasil yang didapatkan saturasi oksigen menunjukkan tidak ada perbedaan antara kelompok sebelum suction. Segera setelah suction, saturasi oksigen menurun secara signifikan pada kelompok suction terbuka, sedangkan nilai saturasi oksigen tidak berubah setelah suction pada kelompok suction tertutup. Dengan demikian kelompok suction terbuka memiliki saturasi rendah setelah tindakan suction dengan nilai signifikan dibandingkan dengan pasien dalam kelompok suction tertutup (Rabitsch, dkk. 2004).

\section{Hasil Uji Perbandingan Saturasi Oksigen} Rata-rata Sebelum dan Saat Suction

Simpulan dari hasil uji beda rata-rata (Uji t) di atas adalah bahwa derajat kepercayaan sebesar 95\% pada perbandingan kelompok kontrol dengan kelompok perlakuan didapat nilai $t$ hitung $(-16.538)<t$ tabel $(-2.024)$ dan nilai $p$-value $(0.000)<0.05$, dimana saturasi oksigen saat suction pada kelompok kontrol (tanpa suplai oksigen) adalah memang berbeda secara nyata, hasil penelitian dengan menggunakan catheter mouth pada semua kasus pasien cedera kepala berat dengan pola napas kontrol lebih baik hasilnya dibandingkan dengan tanpa menggunakan catheter mouth karena selama pelaksanaan tindakan suction pasien masih tetap mendapatkan oksigenasi (Jongerden, Rovers, Grypdonck, \& Bonten, 2007).
Pemberian oksigenasi yang adekuat pada pasien yang mengalami hipoksia atmosfer atau pasien yang tidak mendapatkan ventilasi dan oksigen adalah sangat bermanfaat karena terapi oksigen pada keadaan ini dapat meningkatkan oksigenasi di arteri perifer dan alveoli paru-paru. Hal ini dapat dilakukan dengan melihat langsung kadar saturasi oksigen pada monitor dan hasil analisis gas darah. Pada pasien cedera kepala yang mengalami penurunan aliran darah otak, tindakan tersebut sangat bermanfaat agar otak tetap mendapatkan oksigenasi sehingga kekurangan oksigen dapat dihindari (Guyton \& Hall, 2008).

Hasil tersebut membuktikan bahwa penggunaan catheter mouth pada kelompok perlakuan lebih efektif dilakukan pada saat suction untuk mengurangi risiko terjadinya penurunan saturasi oksigen pada pasien cedera kepala berat yang terpasang ventilator dibandingkan dengan kelompok kontrol yang tidak dipasang catheter mouth yang terbukti terjadi penurunan saturasi oksigen yang sangat signifikan. Penggunaan sistem tertutup ini dilakukan untuk mencegah terjadinya desaturasi oksigen sistemik vena dan arteri serta kerusakan paru selama volume ventilasi yang terkontrol (Almgren, dkk., 2004).

Penelitian ini juga pernah dilakukan sebelumnya di negara Amerika saat tindakan bronchoscopy. Pasien yang akan dilakukan tindakan bronchoscopy dipasang catheter mouth, sehingga pada saat dilakukan bronchoscopy pasien tetap mendapatkan suplai oksigen yang adekuat. Hasil yang didapatkan dari penelitian tersebut membukan bahwa penggunaan catheter mouth lebih efektif karena dapat melakukan tindakan dengan waktu lebih lama dan pasien tetap mendapatkan ventilasi saat tindakan (American College of Chest Physicians, 2008).

Tindakan suction endotracheal yang dilakukan pada pasien yang dirawat dengan menggunakan ventilator diperlukan untuk menghilangkan sekresi untuk mencegah obstruksi pada saluran endotracheal dan saluran udara lebih rendah. Prosedur ini sangat umum menciptakan berbagai macam gangguan jantung-paru. Sistem tertutup memungkinkan ventilasi selama pelaksanaan prosedur pengisapan lendir (suction), 
menghindari pemutusan dari ventilator. Dengan demikian, efek samping yang kurang dari sistem suction tertutup telah dievaluasi secara menyeluruh ketimbang efektivitas penghilangan sekresi (Lindgren, 2007).

\section{Simpulan}

Hasil penelitian ini membuktikan bahwa terdapat pengaruh suplai oksigen melalui catheter mouth saat suction terhadap saturasi oksigen pada pasien cedera kepala yang terpasang ventilator, dimana penggunaan catheter mouth lebih efektif digunakan pada saat suction untuk mengurangi risiko terjadinya penurunan saturasi oksigen pada pasien cedera kepala berat yang terpasang ventilator dibandingkan dengan yang tidak menggunakan catheter mouth.

Hasil penelitian ini dapat dijadikan acuan atau evidence based bagi perawat di ruang perawatan intensif untuk meningkatkan pelayanan perawatan. selain itu, penelitian ini juga dapat digunakan sebagai pedoman dalam melakukan tindakan suction untuk mengurangi risiko terjadinya penurunan saturasi oksigen pada pasien cedera kepala berat yang terpasang ventilator.

\section{Daftar Pustaka}

Almgren, B., Carl, J.W., Heinonen, \& E., Hogman, M. (2004). Side effects of endotracheal suction in pressure and volume controlled ventilation. CHEST Journal, 125, 1077-1080.

American College of chest physicians. (2010). Chest Journal. Diakses dari http://www.chestjournal.org/cgi/content/ abstract $/ 83 / 621$.

AARC Clinical Practice Guidelines. (2010). Endotracheal suctioning of mechanically ventilated patients with artificial airways 2010. Respiration Care, 55(6), 758-64. Diakses dari http://www.rcjournal.com/cpgs/ pdf/06.10.0758.pdf.

Dahlan, M.S. (2009). Besar sampel dan cara pengambilan sampel (Edisi ke-2). Jakarta: Salemba Medika.

Guyton, C.A \& Hall, E,J. (2008). Buku ajar fisiologi kedokteran (Edisi ke-11). Jakarta: EGC.

Hudak, M.C \& Gallo, M.B. (2010). Keperawatan kritis (Edisi ke-6, Volume II). Jakarta: EGC.

Jongerden, I.P., Rovers, M.M., Grypdonck, M.H., Bonten, M.J. (2007). Open and closed endotracheal suction systems in mechanically ventilated intensive care patients: MetaAnalysis. Critical care Med, 35(1), 260-270. Diakses dari http:/www.medscape.com/ viewarticle/552222_print.

Lindgren, R.M. (2007). Open and closed endotracheal suctioning: Experimental and human studies (Doktoral thesis,. Institute of Clinical Sciences, Department of Anaesthesiology and Intensive Care, Goteborg University, Sweden). Diakses dari http://gupea.ub.gu.se/bitstream/2077/3325/2/ Spikblad\%20Sophie\%20Lindgren.pdf .

Morrow, B., Futter, \& M., Argent, A. (2006). Effect of endotracheal suction on lung dynamics in mechanically ventilated paediatric patients. Australian Journal of Physiotherapy 52, 121-126. Diakses dari http://ajp.physiotherapy.asn.au/AJP/ vol_52/2/AustJPhysiotherv52i2Morrow.pdf.

Rabitsch, W., Kostler, W.J., Fiebiger, W., Dielacher, C., Losert, H., Sheriff, C., et al. (2004). Closed suctioning system reduces cross-contamination between bronchial System and Gastric Juices. Anesthesia Analgesia, 99(3), 886-92. Diakes dari http://www.an ethesia-analgesia.org/ content/99/3/886.full.

Reilly \& Bullock. (2007). Head injury : pathophysiology and management of severe closed injury. Australia: Chapman \& Hall Medical.

Ridling, D.D.A., Martin, L.D., \& Bratton, S.L. (2003). Endotracheal suctioning with 
Marlisa: Suplai Oksigen melalui Catheter Mouth pada Saat Suction

or without instillation of isotonic sodium chloride solution in critically III children. Am j Crit Care, 12(3), 212-9. Diakses dari http://www.ajcconline.org.

Ragnarsson \& Kristjan T. M. (2006). Traumatic brain injury research since the $1998 \mathrm{NIH}$ consensus conference: accomplishments and unmet goals. Journal of Head Trauma Rehabilitation, 21(5), 379-387. Diakses dari http://journals.lww. com/headtraumarehab/Abstract/2006/09000/
Traumatic_Brain_Injury_Research_Since the_1998_NIH.2.aspx.

Sole. (2005). Critical care nursing (5th ed.). St.Louis Missouri: Saunders.

Wheeless, C.R. (2010). Wheeless textbook of orthopaedics : management of head injury. CHEST Journal. Diakses dari http://www. wheelessonline.com/ortho/management_of head_injury_spinal_injury. 